\title{
Insulin-like growth factor binding proteins- 2 to -6 are expressed by human vascular smooth muscle cells
}

\author{
P Andersson ${ }^{1}$, T Gustafsson ${ }^{1}$ and $\mathbf{H}$ J Arnqvist ${ }^{1,2}$ \\ ${ }^{1}$ Department of Biomedicine and Surgery, Division of Cell Biology, Faculty of Health Sciences, Linköping University, S-581 85 Linköping, Sweden \\ ${ }^{2}$ Department of Medicine and Care, Division of Internal Medicine, Faculty of Health Sciences, Linköping University, S-581 85 Linköping, Sweden \\ (Requests for offprints should be addressed to P Andersson)
}

\begin{abstract}
We have investigated the expression and secretion of insulin-like growth factor binding proteins (IGFBPs-1 to -6) in human vascular smooth muscle cells (hVSMCs) cultured from human renal arteries. Solution hybridization was used to determine IGFBP mRNA levels and Western immunoblot to detect the corresponding peptides. The hVSMCs expressed mRNAs for IGFBPs-2 to -6; IGFBP1 mRNA was not detected. IGFBPs- $3,-4$ and -6 mRNAs were the most abundant, IGFBP-5 was also highly expressed, whereas the IGFBP-2 mRNA was just above the limit of detection. Serum starvation for $48 \mathrm{~h}$ significantly decreased the mRNA levels of IGFBPs- 2 to -5 and tended to decrease IGFBP-6 mRNA also. IGFBPs-2, -4 , -5 and -6 peptides could be detected in conditioned
\end{abstract}

medium, but IGFBP-3 peptide was not detected. IGFBP-4 was the only peptide detected without any concentration step. Low-molecular-mass immunoreactive degradation products were found for IGFBPs -2 and -4 . Exogenous IGFBPs-1, -3 and -4 in concentrations of $50 \mathrm{ng} / \mathrm{ml}$ inhibited DNA synthesis induced by $1 \mathrm{nM}$ IGF-I, whereas IGFBPs-2, -5 and -6 had no significant inhibitory effects at this concentration. We conclude from these results that all IGFBPs except IGFBP-1 are expressed in hVSMC. Our results indicate that locally produced, in addition to circulating, IGFBPs may have an important role in the regulation of hVSMC.

Journal of Endocrinology (1999) 163, 281-288

\section{Introduction}

Vascular smooth muscle cells (VSMCs) are important structural components of the arterial wall. Although they are normally quiescent, VSMCs proliferate during development of atherosclerotic lesions, and proliferation of VSMC is the cause of restenosis after angioplasty (Schwartz et al. 1990, Ross 1993). Insulin-like growth factor (IGF)-I is a growth factor for VSMCs both in vitro and in vivo (Bornfeldt et al. 1991, Arnqvist et al. 1995) and also stimulates their migration (Bornfeldt et al. 1995).

The bioavailability of IGF-I is regulated by at least six high-affinity IGF binding proteins (IGFBPs-1 to -6) (Jones \& Clemmons 1995, Kelley et al. 1996). IGFBPs regulate the availability of IGFs-I and -II by serving as transporter proteins and as storage pools. Furthermore, they are important modulators of IGF action at the cellular level. Recent data suggest that they also may have biological activities independent of the IGFs, possibly acting through receptors of their own (Liu et al. 1992, Jones et al. 1993a, Oh et al. 1993a). The IGFBPs exhibit different properties, and their gene expressions are differently regulated by hormones, growth factors and cytokines (Kamyar et al. 1994, McCusker \& Clemmons 1994, Fan et al. 1996, Zhou et al. 1996). The affinities of the IGFBPs for IGF-I differ, showing at the most a one-hundredfold variation (Oh et al. 1993b). Structurally, IGFBPs contain two globular, well-conserved domains, with an intermediate non-conserved domain connecting the other two (Spencer \& Chan 1995). IGFBPs-3 to -6 are glycosylated at certain amino acid residues, and IGFBPs- $1,-3$ and -5 can be phosphorylated to different degrees (Kelley et al. 1996). IGFBPs-1 and -2 contain RGD sequences, whereas all IGFBPs except IGFBP-4 contain heparinbinding sequences (Bourner et al. 1992, Jones et al. 1993b, Hodgkinson et al. 1994, Gockerman et al. 1995). The discovery of specific proteases for IGFBPs has led to new insights as to how IGFBPs regulate IGF-action. To date, proteases for IGFBPs-2 to -5 have been described (Collett-Solberg \& Cohen 1996).

Previous studies have demonstrated that rat and porcine VSMC express and secrete IGFBPs-2, -4 and -5 mRNAs and proteins respectively (Giannella-Neto et al. 1992, Cohick et al. 1993, Kamyar et al. 1994, Duan et al. 1996) and bovine VSMC IGFBPs-3 and -4 mRNAs (Boes et al. 1996). To our knowledge, there has been no systematic study of which IGFBPs are expressed and secreted by VSMCs from different species, and there is only one 
published study of human VSMCs (Boes et al. 1996). The purpose of the present study was to investigate the basal expression and secretion of the different IGFBPs in human VSMCs. In addition, we studied the effects of recombinant IGFBPs-1 to -6 on IGF-I-induced DNA synthesis.

\section{Materials and Methods}

\section{Cell culture technique}

Human vascular smooth muscle cells (hVSMCs) were cultured from renal artery, using an explant technique (Ross 1971). The hVSMCs were allowed to migrate from the primary explants and were subsequently passaged at confluence. Cells were maintained in F12-medium containing $15 \%$ fetal bovine serum, $0.05 \mathrm{mg} / \mathrm{ml}$ ascorbic acid, $2 \mu \mathrm{g} / \mathrm{ml}$ fungizone and $200 \mathrm{IU} / \mathrm{ml}$ penicillin. Culturing was performed at a temperature of $37^{\circ} \mathrm{C}$, humidity of $85 \%$ and at a $\mathrm{CO}_{2}$ concentration of $5 \%$ in air. The medium was changed twice a week and the cells were harvested at passages $2-8$ using a solution of trypsin $(0 \cdot 25 \%)$ and EDTA $(0.02 \%)$. The cells were characterized as smooth muscle cells both by morphological criteria and by a human $\alpha$-actin antibody that recognizes a unique epitope of $\alpha$-actin (Skalli et al. 1986). In control experiments, the $\alpha$-actin antibody did not bind to cells from a breast cancer cell line, MCF-7 (data not shown). On the basis of morphology and our experiments with the $\alpha$-actin antibody, the cells were identified as a uniform population of smooth muscle cells. The viability of the cells was good, and the cells survived serum starvation for at least $48 \mathrm{~h}$ without detaching or changing morphology.

\section{$\left.P^{3} H\right]$ Thymidine incorporation into DNA}

DNA synthesis was quantified by measuring incorporation of $\left[{ }^{3} \mathrm{H}\right]$ thymidine into DNA. The cells were grown in 24-well plates and incubated for $24 \mathrm{~h}$ with the addition of $1 \mu \mathrm{Ci} / \mathrm{ml}\left[{ }^{3} \mathrm{H}\right]$ thymidine and in the presence or absence of IGF-I and the different IGFBPs at indicated concentrations. The cells were washed with F12-medium and DNA was precipitated with $5 \%$ ice-cold trichloroacetic acid (TCA). DNA was solubilized in $0 \cdot 1 \mathrm{M} \mathrm{KOH}, 500 \mu \mathrm{l}$ of the solution in each well was added to scintillation liquid and the radioactivity was counted in a liquid scintillation counter. Data were expressed as \% of control cells, incubated without reagents.

\section{Solution hybridization/RNase protection assay}

The near-confluent cells from three Petri dishes (diameter $100 \mathrm{~mm}$ ) were harvested either directly or after $48 \mathrm{~h}$ of serum starvation in $1 \times$ SET buffer (1\% SDS, $10 \mathrm{mM}$ EDTA, $20 \mathrm{mM}$ Tris, $\mathrm{pH} 7 \cdot 5$ ) and homogenized with a polytron. Proteinase K was added and the samples were extracted with phenol and chloroform according to the method of Durnam \& Palmiter (1983). Total nucleic acids were precipitated in 95\% ethanol. The DNA content was measured as described by Labarca et al. (1980). The mRNA levels for IGFBPs-1 to -6 were analysed with a solution hybridization assay using $\left[{ }^{35}\right.$ S]UTP-labelled RNA-probes. The IGFBP-1 probe was synthesized from $350 \mathrm{bp}$ of a human cDNA (Brinkman et al. 1988), the IGFBP-2 probe from $446 \mathrm{bp}$ of a human cDNA (Binkert et al. 1989), the IGFBP-3 probe from $475 \mathrm{bp}$ of a human cDNA (Wood et al. 1988), the IGFBP-4 probe from $505 \mathrm{bp}$ of a human cDNA (Shimasaki et al. 1990), the IGFBP-5 probe from $317 \mathrm{bp}$ of a human cDNA (Shimasaki et al. 1991b), and the IGFBP-6 probe from $267 \mathrm{bp}$ of a human cDNA (Shimasaki et al. 1991a). The probes were prepared as described earlier by Melton et al. (1984). The samples were hybridized with their probe for $18 \mathrm{~h}$, at $70^{\circ} \mathrm{C}$. The hybridization solution contained a total volume of $40 \mu \mathrm{l} 0.6 \mathrm{M} \mathrm{NaCl}, 20 \mathrm{mM}$ Tris, $4 \mathrm{mM}$ EDTA, $0.75 \mathrm{mM}$ dithiothreitol, $25 \%$ formamide and $0.1 \%$ SDS. At least 10000 c.p.m. $\left[{ }^{35}\right.$ S]UTP-labelled probe was used per hybridization. RNases were then added and the double-stranded RNA was precipitated in 6 M TCA. The hybrids were collected on a filter and the radioactivity was counted in a liquid scintillation counter.

For quantitative analysis of mRNA, a standard curve was included in each assay. The curve was created by hybridizing known amounts of in vitro-synthesized standard (sense) RNA with probe (antisense). By comparing the sample values with the values of the curve, a quantitative measure of mRNA could be given. The amount of mRNA was then related to the amount of DNA measured in the extract of total nucleic acid as described above and expressed as amol/ $\mu \mathrm{g}$ DNA.

To control the specificity of the probes for IGFBPs- 1 to -6 , each probe was hybridized to every sense strand of IGFBPs-1 to -6. No hybrids could be detected, indicating that no cross-reactivity between the probes took place. The results thus showed that although the IGFBPs are structurally closely related, each probe bound only to its complementary sense strand, indicating that the IGFBP probes were specific for their sense RNA.

\section{Immunodetection of IGFBPs in hVSMC conditioned medium}

Conditioned medium from three Petri dishes (diameter $100 \mathrm{~mm}$ ), was collected after $48 \mathrm{~h}$ of serum deprivation. EDTA at a final concentration at $5 \mu \mathrm{M}$ was added in order to prevent protease activity. The conditioned medium was concentrated with a final concentration of 5\% TCA and the proteins were co-precipitated with $50 \mu \mathrm{l} 0 \cdot 1 \% \mathrm{BSA}$ and kept on ice over night. Finally, the conditioned medium was centrifuged at 11000 r.p.m. for $30 \mathrm{~min}$ at $4{ }^{\circ} \mathrm{C}$ and the pellets were dissolved in electrophoresis sample buffer, obtaining a 20-fold concentration. 
The concentrated samples were heated at $95{ }^{\circ} \mathrm{C}$ for 3 min before samples were applied to a $15 \%$ SDSpolyacrylamide gel. The size-fractionated proteins were electroblotted onto polyvinylidene difluoride membranes for $1 \mathrm{~h}$ at $200 \mathrm{~mA}$. The membranes were blocked in a buffer containing polyvinylalcohol $(0 \cdot 2 \%)$ low molecular range in PBS $\mathrm{pH} 7.5$ for $1 \mathrm{~h}$ at $20{ }^{\circ} \mathrm{C}$ or over night in a refrigator. The membranes were washed once for $15 \mathrm{~min}$ and twice for $5 \mathrm{~min}$ with Tris-buffered saline with Tween (TBS-T) $(0 \cdot 1 \%)$ and then incubated with specific antibodies for $1 \mathrm{~h}$ at $20^{\circ} \mathrm{C}$ (with gentle shaking), IGFBP-2 and IGFBP-4 antisera with a $1: 2000$ dilution, IGFBP-5 antiserum with a $1: 1500$ dilution and IGFBP-3 and IGFBP-6 antisera with a $1: 1000$ dilution. The membranes were then washed as above in TBS-T $(0 \cdot 1 \%)$. After incubation with a second anti-immunoglobulin $G$ antibody coupled to horseradish peroxidase, the membranes were washed as above. Finally the proteins were visualized by chemiluminescence using the enhanced chemiluminescence Western blotting detection system (Amersham Int., Amersham, Bucks, UK).

\section{Materials}

Proteinase K was from Merck (Darmstadt, Germany), $\left[{ }^{35} \mathrm{~S}\right]$ UTP, $\left[{ }^{3} \mathrm{H}\right]$ leucine and $\left[{ }^{3} \mathrm{H}\right]$ thymidine were from Amersham Int. and the chemicals for antisense (probe) and sense (standard) synthesis from Promega (Madison, WI, USA). RNase A, RNase T1 and herring sperm DNA were obtained from Boehringer (Mannheim, Germany). Phenol was from Fisher Scientific (Fair Lawn, NJ, USA), trypsin from Difco Labs (Detroit, MI, USA) and collagenase type I from Sigma (St Louis, MO, USA). Scintillation liquid (Ultima Gold) was obtained from Packard Instrument Company (Meriden, CT, USA). The monoclonal antibody against $\alpha$-smooth muscle actin was from Sigma Immuno Chemicals (La Jolla, CA, USA). Chemicals and solutions for cell culture were from Gibco Brl Life Technologies (Täby, Sweden). Recombinant human IGFBPs-2, -4, -5 and -6 peptides were purchased from Austral Biologicals (San Ramon, CA, USA). Recombinant IGFBP-3 was purchased from Upstate Biotechnology, Inc. (Lake Placid, NY, USA). Antibodies for IGFBPs-2, -3 and -4 were purchased from Upstate Biotechnology, Inc. (Lake Placid, NY, USA). Antibodies for IGFBPs-5 and -6 were purchased from Austral Biologicals (San Ramon, CA, USA). Recombinant IGF-I was a gift from Pharmacia Upjohn (Stockholm, Sweden).

\section{Statistical analysis}

Values are reported as means \pm S.E.M. Data were analysed using standard statistical methods including ANOVA (Scheffe's test), Student's $t$-test and linear regression analysis. A value of $P \leq 0.05$ was considered to be significant.

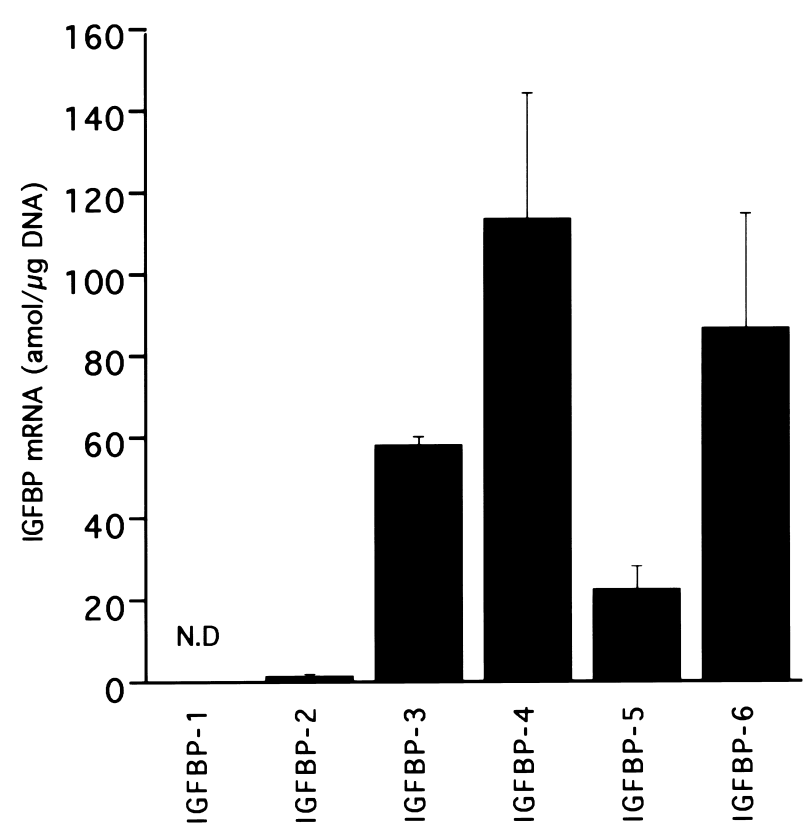

Figure 1 Gene expression of IGFBPs- 1 to -6 in hVSMCs. hVSMCs were seeded out in Petri dishes (150000 cells/dish) and harvested after 4 days, when reaching near-confluency. The mRNA levels were determined by solution hybridization as described in Materials and Methods. Samples were analysed in triplicate. Values are given as means \pm S.E.M., $n=4$.

\section{Results}

\section{IGFBP $m R N A$ levels in hVSMCs}

The mRNAs for IGFBPs-1 to -6 were measured by solution hybridization in hVSMCs. We were able to show that hVSMCs express mRNAs for IGFBPs-2 to -6 (Fig. 1). IGFBP-1 mRNA was not detected with our assay (limit of detection $0 \cdot 1 \mathrm{amol} / \mu \mathrm{g}$ DNA). IGFBPs-4, IGFBP-6 and IGFBP-3 mRNAs were the most highly expressed, IGFBP-5 was highly expressed, and IGFBP-2 mRNA was just above the limit of detection (Fig. 1). To test if the expression of IGFBPs is regulated by serum factors, we measured mRNA levels after $48 \mathrm{~h}$ of serum deprivation. The mRNA levels of IGFBPs- 2 to -5 were decreased significantly when serum was omitted, and that of IGFBP-6 tended to be decreased also (Fig. 2).

\section{IGFBPs in conditioned medium}

To determine if IGFBP mRNA expression is associated with the release of the corresponding IGFBPs, conditioned medium from the hVSMCs was analysed by Western immunoblot. IGFBPs-2, $-4,-5$ and -6 could be detected in the conditioned medium (Fig. 3). We were not able to detect IGFBP-3, despite the fact that the peptide could be detected in human serum with the antibody used (data not shown). IGFBP-4 was the only protein that could be 


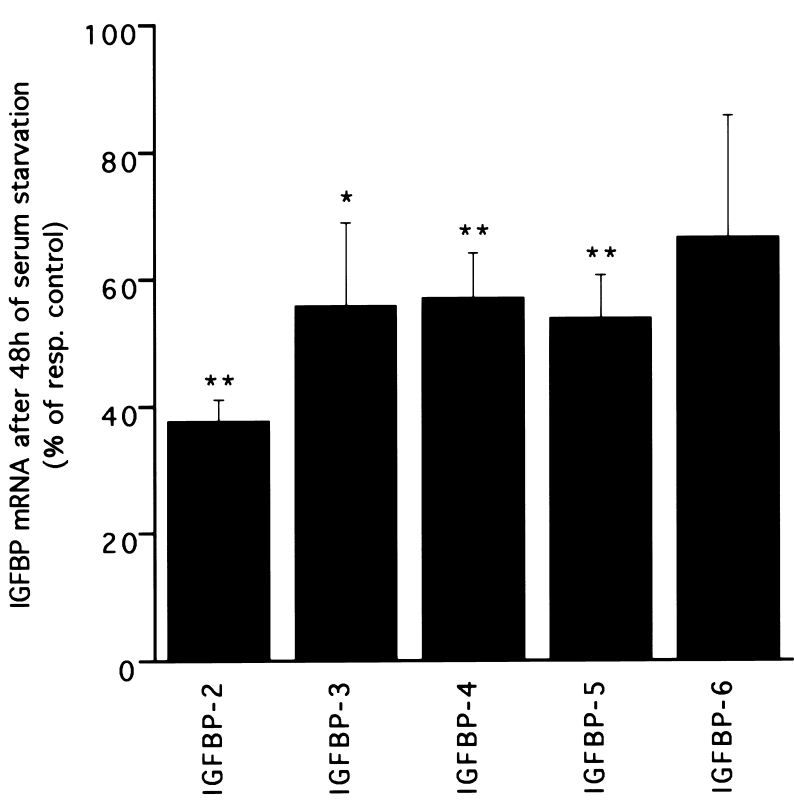

Figure 2 Effect of serum starvation on expression of IGFBPs-2 to -6 mRNAs in hVSMCs. The cells were seeded out in Petri dishes (150 000 cells/dish) and cultured for 4 days until near-confluency. They were then serum-starved for $48 \mathrm{~h}$. The cells were harvested and the mRNA levels were determined by solution hybridization as described in Materials and Methods. Data are given as \% of respective (resp.) control (not serum-deprived hVSMCs) and presented as means \pm S.E.M. Statistical comparisons were made according to Student's one way $t$-test. ${ }^{*} P<0 \cdot 05,{ }^{*} P<0 \cdot 01$ compared with respective control.

detected without any concentration step. Low-molecularmass immunoreactive bands appeared for IGFBP-2 at 20 $\mathrm{kDa}$ and for IGFBP-4 at $16 \mathrm{kDa}$, suggesting degradation products. IGFBPs-4 and -6 were identified with double bands, indicating a possible glycosylation of these IGFBPs.

\section{Effects of IGFBPs on IGF-I-induced DNA synthesis}

IGF-I induced DNA synthesis in a dose-dependent way (Fig. 4). $\mathrm{EC}_{50}$ was calculated as $0 \cdot 1 \mathrm{nM}$ and an IGF-I concentration of $1 \mathrm{nM}$ gave a maximal effect. IGF-I (1 $\mathrm{nM}$ ) was subsequently added together with $50 \mathrm{ng} / \mathrm{ml}$ of the respective IGFBP. In a concentration of $50 \mathrm{ng} / \mathrm{ml}$, IGFBPs-1, -3 and -4 significantly inhibited IGF-Iinduced DNA synthesis (Fig. 5). IGFBP-2 tended to inhibit IGF-I action, whereas IGFBPs- 5 and -6 had no effect (Fig. 5). IGFBPs-1 to -6 added alone had no significant effects compared with control (Fig. 5).

\section{Discussion}

\section{Expression of IGFBP $m R N A$ s in human VSMCs}

In this study, we have shown that VSMC derived from human renal artery express IGFBPs- 2 to -6 , and that the corresponding proteins could be demonstrated for IGFBPs-2, -4, -5 and -6. Boes et al. (1996) have recently shown that human VSMC cultured from aorta, coronary and pulmonary arteries express IGFBPs- $3,-4$ and -6 , according to standard Northern blot analysis. These IGFBPs were also the most highly expressed binding proteins in our study, with IGFBP-4 mRNA being most abundant. However, we were also able to detect considerable amounts of IGFBP- 5 mRNA. In addition, low amounts of IGFBP-2 mRNA (just above the limit of detection of our assay) were detected. Boes et al. (1996) were able to detect robust bands for IGFBP-2 mRNA in human pulmonary SMC using reverse transcription PCR, whereas faint bands were shown with IGFBPs- 1 and -5 primers. A difference between our study and that of Boes et al. (1996) is our detection of high levels of IGFBP5 mRNA. To our knowledge, these two reports are the only studies investigating IGFBP gene expression in human VSMCs.

Bovine aortic SMCs have been shown to express predominantly IGFBPs-3 and -4 (Boes et al. 1996). Porcine VSMCs have previously been shown to express IGFBPs-2, -4 and -5 mRNAs (Cohick et al. 1993, Duan et al. 1996), and rat VSMCs seem to express predominantly IGFBPs-2 and -4 (Kamyar et al. 1994). According to the available data, there seem to be species differences in IGFBP gene expression in VSMCs. In all species, IGFBP-1 is either not or only very faintly expressed in VSMCs.

\section{IGFBP protein levels in $h V S M C$ conditioned medium}

We were able to detect IGFBPs-4 and -6 peptides in large amounts in the hVSMC conditioned medium after $48 \mathrm{~h}$ of serum-free incubation. IGFBP-3 peptide could not be detected, and IGFBP-5 peptide was detected only with a faint band, despite their high mRNA levels. In contrast to this, IGFBP-2 peptide was detected in about the same concentrations as those shown for IGFBPs- 4 or -6 . Boes et al. (1996) have described that human aortic SMCs, in common with coronary and pulmonary artery SMCs, secrete IGFBPs-3 and -4 , and a $30 \mathrm{kDa}$ IGFBP, identified as IGFBP-6. In comparison with their study, our results differed with respect to our detection of high concentrations of IGFBP-2 peptide, our failure to demonstrate IGFBP-3, and our detection of IGFBP-5. In another study (van der Ven et al. 1996), IGFBP-3 was determined by RIA in concentrations of $13-288 \mathrm{ng} / \mathrm{ml}$ in the conditioned medium of human uterine SMC. Interestingly, high intensity immunostaining was located on SMC membranes and in the cytoplasm. A high degree of IGFBP-3 binding to the SMC could be one explanation of why we fail to detect IGFBP-3; another reason could be high protease activity, as demonstrated by Boes et al. (1996), although no immunoreactive degradational products were found in our Western blots. However, the 


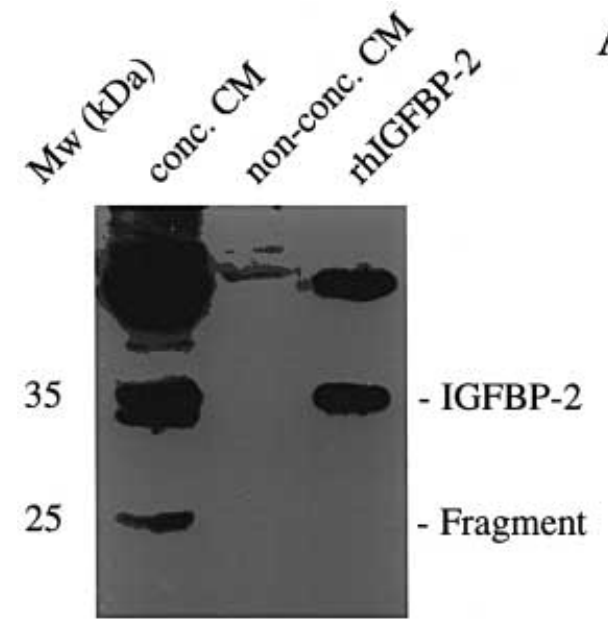

A

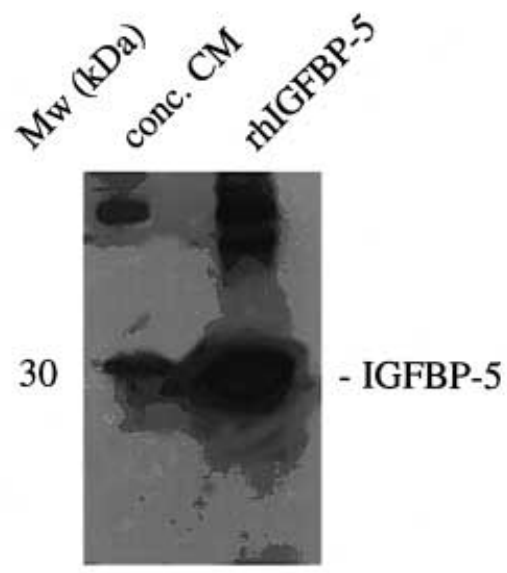

C

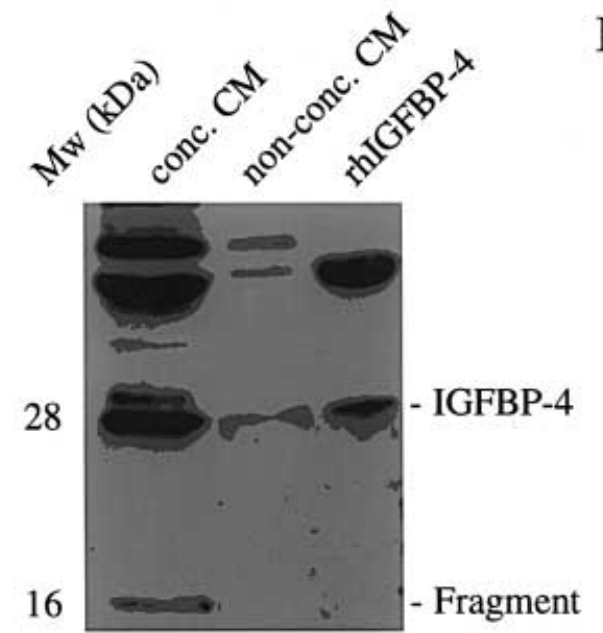

B

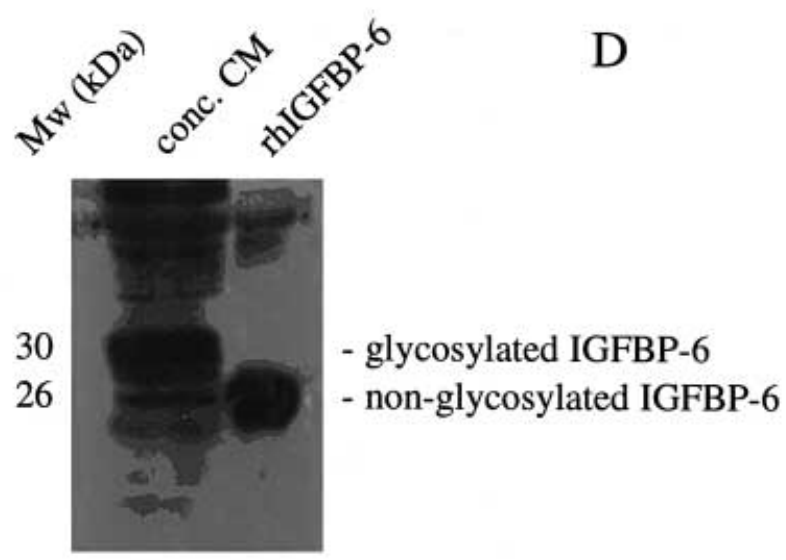

Figure 3 Levels of (A) IGFBP-2, (B) IGFBP-4, (C) IGFBP-5 and (D) IGFBP-6 peptides in conditioned medium (CM). Near-confluent hVSMCs were serum-starved and after $48 \mathrm{~h}$ the conditioned medium was collected, concentrated $(1: 20)$ and subjected to Western immunoblot analysis as described in Materials and Methods. Major bands at higher molecular masses $(\mathrm{Mw})$ in all blots at approximately $65 \mathrm{kDa}$ are bovine serum albumin. The figures show representative data $(n=3)$.

antibody may not have affinity for the degradation products. Experience from other species suggests that IGFBPs-2, -4 and -5 are secreted from porcine VSMCs (Cohick et al. 1993, Duan et al. 1996) and predominantly IGFBPs-2 and -4 from rat VSMCs (Kamyar et al. 1994); bovine VSMCs have been found to secrete IGFBP-4 and barely detectable levels of IGFBP-3 (Boes et al. 1996).

\section{Regulation of IGFBP $m R N A$ s and peptides}

A trend observed in our study was a downregulation of IGFBP mRNA in hVSMCs that were serum-deprived for $48 \mathrm{~h}$, compared with cells grown in serum-containing medium. IGFBPs-3, -4 and -5 mRNAs were significantly decreased after $48 \mathrm{~h}$ of serum deprivation, and IGFBPs- 2 and -6 tended to be decreased.
Grant et al. (1996) were unable to detect IGFBPs-1 to -5 in smooth muscle layers of normal human coronary artery when using immunocytochemistry. Furthermore, IGF-I and the type I IGF receptor were not found. However, all the IGFBPs, in addition to IGF-I and its receptor, were localized in the cytoplasm of synthetic SMC in atherectomy plaques. This suggests that expression of the IGF-system in VSMCs is a reflection of the phenotype of the cells.

We found low-molecular-mass immunoreactive bands for IGFBPs- 2 and -4 in the conditioned medium of the hVSMCs. This has previously been described in porcine VSMCs by Gockerman \& Clemmons (1995) and by Parker et al. (1995), indicating the presence of fragments of these IGFBPs. Proteases secreted by rat and porcine VSMCs have also been reported for these IGFBPs 


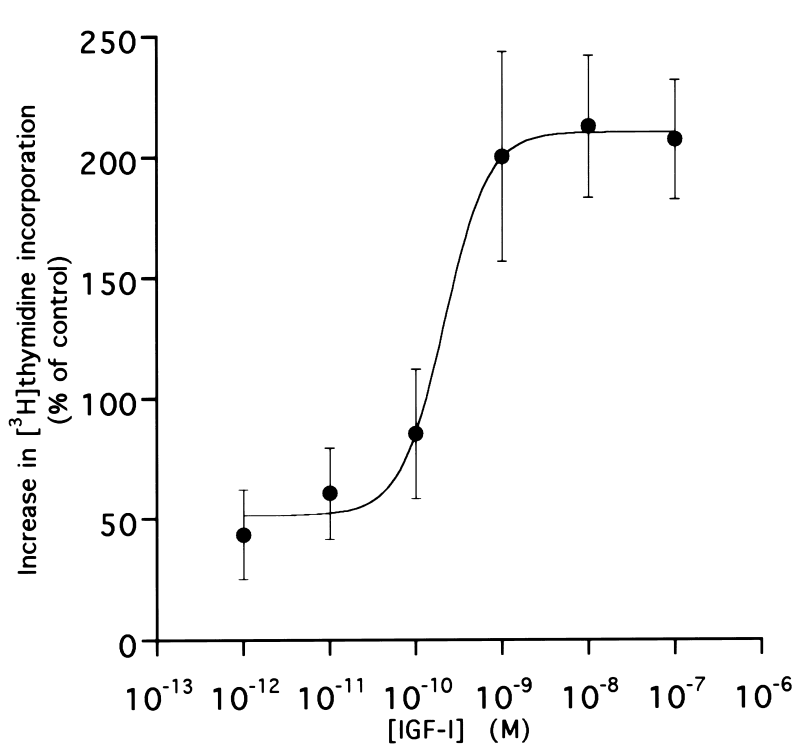

Figure 4 Dose-response curve for IGF-I-stimulated DNA synthesis in cultures of hVSMCs. Values represent \% of control values. Near-confluent cell cultures were starved for $24 \mathrm{~h}$ and subsequently exposed to IGF-I $\left(10^{-6}-10^{-12} \mathrm{M}\right)$ for $24 \mathrm{~h}$, after which $\left[{ }^{3} \mathrm{H}\right]$ thymidine incorporation was determined. Values are given as means \pm S.E.M., $n=3$; samples were measured in triplicate.

(Kamyar et al. 1994, Gockerman \& Clemmons 1995, Parker et al. 1995). The specific proteases secreted from human VSMCs need to be characterized.

\section{Modulatory actions of IGFBPs on IGF-I-induced DNA synthesis}

The stimulatory action of IGF-I on DNA synthesis in human VSMCs reached a maximal effect at a concentration of $1 \mathrm{nM}$, which was subsequently used in the experiments performed with IGFBPs. Each of the IGFBPs was added in a concentration of $50 \mathrm{ng} / \mathrm{ml}(1 \cdot 4 \mathrm{nM}-2 \cdot 0$ $\mathrm{nM})$, which is about equimolar to the concentration of IGF-I (1nM) used. In the present study, IGFBPs- $1,-3$ and -4 were potent inhibitors of IGF-I $(1 \mathrm{nM})$-induced DNA synthesis, whereas IGFBPs-2, -5 and -6 had no significant effects. IGFBPs- $1,-3,-4$ and -5 have about the same $K_{\mathrm{a}}$ value $\left(20 \times 10^{-9} \mathrm{M}^{-1}\right)$ (Martin \& Baxter 1986, Jones et al. 1991, Kiefer et al. 1992) for IGF-I, whereas IGFBPs-2 and -6 have a lower $K_{\mathrm{a}}$ value $\left(1 \times 10^{-9} \mathrm{M}^{-1}\right)$ (Roghani et al. 1991, Kiefer et al. 1992). The inhibitory actions of the IGFBPs are in agreement with their affinity for IGF-I, with the exception for IGFBP-5. IGFBP-5 is rapidly degraded, and this could be one explanation for its lack of effect (Imai et al. 1997). We have previously shown that IGFBPs-1, -2 and -4 all dose-dependently inhibit IGF-Iinduced DNA and protein synthesis in rat VSMCs (Gustafsson et al. 1999), IGFBPs-1 and -4 being more potent than IGFBP-2. The effects of IGFBPs-3 and

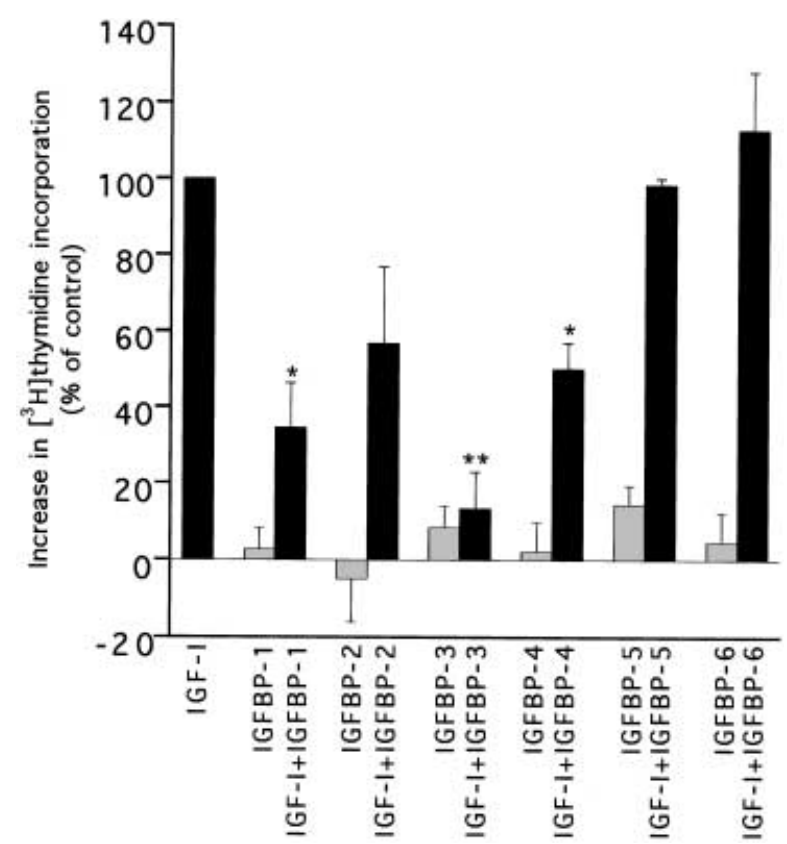

Figure 5 Modulation by IGFBPs- 1 to -6 of the response of hVSMCs to IGF-I. Effect of IGF-I $\left(10^{-9} \mathrm{M}\right)$ added together with IGFBPs- 1 to $-6(50 \mathrm{ng} / \mathrm{ml})$ on $\left[{ }^{3} \mathrm{H}\right]$ thymidine incorporation. Values are given as means \pm S.E.M., $n=4$; samples were measured in triplicate. ANOVA, Scheffé's method, was used for comparing more than two groups. ${ }^{*} P<0 \cdot 05,{ }^{*} P<0 \cdot 01, n=4$.

-6 have been less extensively studied to date. The physiological concentrations of IGFBPs-2, -4 and -6 in the circulation of healthy individuals are about $250 \mathrm{ng} / \mathrm{ml}$, whereas those of IGFBP-1 fluctuate in accordance with the metabolic state $(0-500 \mathrm{ng} / \mathrm{ml})$ (Collett-Solberg \& Cohen 1996); the concentration of IGFBP-3 in the circulation is about $4000 \mathrm{ng} / \mathrm{ml}$ and that of IGFBP-5 approximately $600 \mathrm{ng} / \mathrm{ml}$ (Collett-Solberg \& Cohen 1996). The contribution to the pericellular concentration of IGFBPs that is attributable to IGFBPs produced by VSMCs is not easily measured. However, if IGFBPs in the circulating concentrations gain access to the pericellular space, this will have an inhibitory effect on IGF-Istimulated processes.

In conclusion, this study demonstrates that hVSMCs express mRNAs for IGFBPs-2 to -6 and secrete IGFBPs- $2,-4,-5$ and -6 . IGFBPs $-1,-3$ and -4 have inhibitory actions on IGF-I-induced DNA synthesis in concentrations less than those in the circulation. This suggests that locally produced and circulating IGFBPs are of importance in vascular physiology and in the response to endothelial injury.

\section{Acknowledgements}

Financial support was obtained from Swedish Medical Research Council (19x-4952), the Swedish Diabetes 
Association, Children's Diabetes Foundation and Novo Nordic Foundation.

\section{References}

Arnqvist HJ, Bornfeldt KE, Chen Y \& Lindstrom T 1995 The insulin-like growth factor system in vascular smooth muscle: interaction with insulin and growth factors. Metabolism: Clinical and Experimental 44 58-66.

Binkert C, Landwehr J, Mary JL, Schwander J \& Heinrich G 1989 Cloning, sequence analysis and expression of a cDNA encoding a novel insulin-like growth factor binding protein (IGFBP-2). EMBO Journal 8 2497-2502.

Boes M, Booth BA, Dake BL, Moser DR \& Bar RS 1996 Insulin-like growth factor binding protein production by bovine and human vascular smooth muscle cells: production of insulin-like growth factor binding protein-6 by human smooth muscle. Endocrinology $1375357-5363$.

Bornfeldt KE, Gidlof RA, Wasteson A, Lake M, Skottner A \& Arnqvist HJ 1991 Binding and biological effects of insulin, insulin analogues and insulin-like growth factors in rat aortic smooth muscle cells. Comparison of maximal growth promoting activities. Diabetologia 34 307-313.

Bornfeldt KE, Raines EW, Graves LM, Skinner MP, Krebs EG \& Ross R 1995 Platelet-derived growth factor. Distinct signal transduction pathways associated with migration versus proliferation. Annals of the New York Academy of Sciences 766 416-430 (Review).

Bourner MJ, Busby WH Jr, Siegel NR, Krivi GG, McCusker RH \& Clemmons DR 1992 Cloning and sequence determination of bovine insulin-like growth factor binding protein-2 (IGFBP-2): comparison of its structural and functional properties with IGFBP-1. Journal of Cellular Biochemistry 48 215-226.

Brinkman A, Groffen C, Kortleve DJ, Geurts van Kessel A \& Drop SL 1988 Isolation and characterization of a cDNA encoding the low molecular weight insulin-like growth factor binding protein (IBP-1). EMBO Journal 7 2417-2423.

Cohick WS, Gockerman A \& Clemmons DR 1993 Vascular smooth muscle cells synthesize two forms of insulin-like growth factor binding proteins which are regulated differently by the insulin-like growth factors. Journal of Cellular Physiology 157 52-60.

Collett-Solberg PF \& Cohen P 1996 The role of the insulin-like growth factor binding proteins and the IGFBP proteases in modulating IGF action. Endocrinology and Metabolism Clinics of North America 25 591-614 (Review).

Duan C, Hawes SB, Prevette T \& Clemmons DR 1996 Insulin-like growth factor-I (IGF-I) regulates IGF-binding protein-5 synthesis through transcriptional activation of the gene in aortic smooth muscle cells. Journal of Biological Chemistry 271 4280-4288.

Durnam DM \& Palmiter RD 1983 A practical approach for quantitating specific mRNAs by solution hybridization. Analytical Biochemistry 131 385-393.

Fan J, Wojnar MM, Theodorakis M \& Lang CH 1996 Regulation of insulin-like growth factor (IGF)-I mRNA and peptide and IGF-binding proteins by interleukin-1. American Journal of Physiology 270 R621-R629.

Giannella-Neto D, Kamyar A, Sharifi B, Pirola CJ, Kupfer J, Rosenfeld RG, Forrester JS \& Fagin JA 1992 Platelet-derived growth factor isoforms decrease insulin-like growth factor I gene expression in rat vascular smooth muscle cells and selectively stimulate the biosynthesis of insulin-like growth factor binding protein 4. Circulation Research 71 646-656.

Gockerman A \& Clemmons DR 1995 Porcine aortic smooth muscle cells secrete a serine protease for insulin-like growth factor binding protein-2. Circulation Research 76 514-521.

Gockerman A, Prevette T, Jones JI \& Clemmons DR 1995 Insulinlike growth factor (IGF)-binding proteins inhibit the smooth muscle cell migration responses to IGF-I and IGF-II. Endocrinology 136 4168-4173.

Grant MB, Wargovich TJ, Ellis EA, Tarnuzzer R, Caballero S, Estes K, Rossing M, Spoerri PE \& Pepine C 1996 Expression of IGF-I, IGF-I receptor and IGF binding proteins-1, -2, -3, -4 and -5 in human atherectomy specimens. Regulatory Peptides 67 137-144.

Gustafsson T, Andersson P \& Arnqvist HJ 1999 Different inhibitory actions of IGFBP-1, -2 and -4 on IGF-I effects in vascular smooth muscle cells. Journal of Endocrinology 161 245-253.

Hodgkinson SC, Napier JR, Spencer GS \& Bass JJ 1994 Glycosaminoglycan binding characteristics of the insulin-like growth factorbinding proteins. Journal of Molecular Endocrinology 13 105-112.

Imai Y, Busby WH Jr, Smith CE, Clark JB, Garmong AJ, Horwitz CD, Rees C \& Clemmons DR 1997 Protease resistant form of insulin-like growth factor-binding protein 5 is an inhibitor of insulin-like growth factor-I actions on porcine smooth muscle cells in culture. Journal of Clinical Investigation 100 2596-2605.

Jones JI \& Clemmons DR 1995 Insulin-like growth factors and their binding proteins: biological actions. Endocrine Reviews 16 3-34.

Jones JI, D'Ercole AJ, Camacho-Hubner C \& Clemmons DR 1991 Phosphorylation of insulin-like growth factor (IGF)-binding protein 1 in cell culture and in vivo: effects on affinity for IGF-I. Proceedings of the National Academy of Sciences of the USA 88 7481-7485.

Jones JI, Gockerman A, Busby WH Jr, Camacho Hubner C \& Clemmons DR 1993a Extracellular matrix contains insulin-like growth factor binding protein-5: potentiation of the effects of IGF-I. Journal of Cell Biology 121 679-687.

Jones JI, Gockerman A, Busby WH Jr, Wright G \& Clemmons DR $1993 b$ Insulin-like growth factor binding protein 1 stimulates cell migration and binds to the alpha-5-beta-1 integrin by means of its Arg-Gly-Asp sequence. Proceedings of the National Academy of Sciences of the USA $9010553-10557$.

Kamyar A, Pirola CJ, Wang HM, Sharifi B, Mohan S, Forrester JS \& Fagin JA 1994 Expression and insulin-like growth factor-dependent proteolysis of insulin-like growth factor-binding protein-4 are regulated by cell confluence in vascular smooth muscle cells. Circulation Research 74 576-585.

Kelley KM, Oh Y, Gargosky SE, Gucev Z, Matsumoto T, Hwa V, Ng L, Simpson DM \& Rosenfeld RG 1996 Insulin-like growth factor-binding proteins (IGFBPs) and their regulatory dynamics. International Journal of Biochemistry and Cell Biology 28 619-637.

Kiefer MC, Schmid C, Waldvogel M, Schlapfer I, Futo E, Masiarz FR, Green K, Barr PJ \& Zapf J 1992 Characterization of recombinant human insulin-like growth factor binding proteins 4,5 and 6 produced in yeast. Journal of Biological Chemistry 267 12692-12699.

Labarca C \& Paigen K 1980 A simple, rapid, and sensitive DNA assay procedure. Analytical Biochemistry 102 344-352.

Liu L, Delbe J, Blat C, Zapf J \& Harel L 1992 Insulin-like growth factor binding protein (IGFBP-3), an inhibitor of serum growth factors other than IGF-I and - II. Journal of Cellular Physiology 153 15-21.

McCusker RH \& Clemmons DR 1994 Effects of cytokines on insulin-like growth factor-binding protein secretion by muscle cells in vitro. Endocrinology 134 2095-2102.

Martin JL \& Baxter RC 1986 Insulin-like growth factor-binding protein from human plasma. Purification and characterization. Journal of Biological Chemistry 261 8754-8760.

Melton DA, Krieg PA, Rebagliati MR, Maniatis T, Zinn K \& Green MR 1984 Efficient in vitro synthesis of biologically active RNA and RNA hybridization probes from plasmids containing a bacteriophage SP6 promoter. Nucleic Acids Research 12 7035-7056.

Oh Y, Muller HL, Lamson G \& Rosenfeld RG 1993a Insulin-like growth factor (IGF)-independent action of IGF-binding protein-3 in Hs578T human breast cancer cells. Cell surface binding and growth inhibition. Journal of Biological Chemistry 268 14964-14971. 
Oh Y, Muller HL, Lee DY, Fielder PJ \& Rosenfeld RG 1993 b Characterization of the affinities of insulin-like growth factor (IGF)-binding proteins 1-4 for IGF-I, IGF-II, IGF-I/insulin hybrid, and IGF-I analogs. Endocrinology 132 1337-1344.

Parker A, Gockerman A, Busby WH \& Clemmons DR 1995 Properties of an insulin-like growth factor-binding protein-4 protease that is secreted by smooth muscle cells. Endocrinology 136 2470-2476.

Roghani M, Lassarre C, Zapf J, Povoa G \& Binoux M 1991 Two insulin-like growth factor (IGF)-binding proteins are responsible for the selective affinity for IGF-II of cerebrospinal fluid binding proteins Journal of Clinical Endocrinology and Metabolism 73 658-666.

Ross R 1971 The smooth muscle cell. II. Growth of smooth muscle in culture and formation of elastic fibers. Journal of Cell Biology $\mathbf{5 0}$ 172-186.

Ross R 1993 The pathogenesis of atherosclerosis: a perspective for the 1990s. Nature 362 801-809.

Schwartz SM, Heimark RL \& Majesky MW 1990 Developmental mechanisms underlying pathology of arteries. Physiological Reviews $701177-1209$.

Shimasaki S, Uchiyama F, Shimonaka M \& Ling N 1990 Molecular cloning of the cDNAs encoding a novel insulin-like growth factor-binding protein from rat and human. Molecular Endocrinology 4 $1451-1458$.

Shimasaki S, Gao L, Shimonaka M \& Ling N 1991a Isolation and molecular cloning of insulin-like growth factor-binding protein-6. Molecular Endocrinology 5 938-948.

Shimasaki S, Shimonaka M, Zhang HP \& Ling N $1991 b$ Identification of five different insulin-like growth factor binding proteins
(IGFBPs) from adult rat serum and molecular cloning of a novel IGFBP-5 in rat and human. Journal of Biological Chemistry 266 10646-10653.

Skalli O, Ropraz P, Trzeciak A, Benzonana G, Gillessen D \& Gabbiani G 1986 A monoclonal antibody against alpha-smooth muscle actin: a new probe for smooth muscle differentiation. Journal of Cell Biology 103 2787-2796.

Spencer EM \& Chan K 1995 A 3-dimensional model for the insulin-like growth factor binding proteins (IGFBPs); supporting evidence using the structural determinants of the IGF binding site on IGFBP-3. Progress in Growth Factor Research 6 209-214.

van der Ven LT, Van Buul-Offers SC, Gloudemans T, Bloemen RJ, Roholl PJ, Sussenbach JS \& Den Otter W 1996 Modulation of insulin-like growth factor (IGF) action by IGF-binding proteins in normal, benign, and malignant smooth muscle tissues. Journal of Clinical Endocrinology and Metabolism 81 3629-3635.

Wood WI, Cachianes G, Henzel WJ, Winslow GA, Spencer SA, Hellmiss R, Martin JL \& Baxter RC 1988 Cloning and expression of the growth hormone-dependent insulin-like growth factorbinding protein. Molecular Endocrinology 2 1176-1185.

Zhou Y, Mohan S, Linkhart TA, Baylink DJ \& Strong DD 1996 Retinoic acid regulates insulin-like growth factor-binding protein expression in human osteoblast cells. Endocrinology 137 975-983.

Received 15 July 1998

Revised manuscript received 21 April 1999

Final version received 2 July 1999

Accepted 5 July 1999 